\title{
PENGELOLAAN SAMPAH SWAKELOLA SEBAGAI BENTUK PARTISIPASI MASYARAKAT (KAMPUNG SUKUNAN, KELURAHAN BANYURADEN, SLEMAN - YOGYAKARTA)
}

\author{
Carina Sarasati*)
}

\author{
*)Magister Teknik Arsitektur, Fakultas Teknik, Universitas Diponegoro, \\ Jl. Prof. Soedarto, SH, Kampus Undip Tembalang, Semarang, Indonesia 50275
}

\begin{abstract}
Abstrak
Partisipasi masyarakat merupakan salah satu poin utama dalam penentuan keberhasilan suatu program pembangunan yang terlaksana di suatu wilayah. Hal tersebut berlaku pula dalam pelaksanaan program pengelolaan sampah. Dalam hal ini pengelolaan sampah yang dimaksud adalah pengelolaan sampah swakelola yang merupakan sistem pengelolaan sampah yang mandiri dan produktif yang dilakukan oleh masyarakat baik secara individu maupun berkelompok di tingkat sumber, dalam hal ini adalah rumah tangga (Perda DIY No.10 tahun 2012).

Kampung Sukunan yang berada di Kelurahan Banyuraden, merupakan salah satu wilayah di Kabupaten Sleman, DIY yang menggunakan sistem pengelolaan sampah swakelola di mana masyarakatnya berpartisipasi dari mulai tingkat pengelolaan di rumah tangga hingga TPS. Tidak hanya berhenti di situ, masyarakat Kampung Sukunan juga mengolah sampah-sampah tersebut sehingga volume timbunan sampah yang ada menjadi berkurang dan hasilnya dapat bermanfaat bagi kehidupan masyarakat Kampung Sukunan selanjutnya.

Tujuan dari penelitian ini adalah untuk mengetahui sejauh mana keberhasilan program pengelolaan sampah di Kampung Sukunan yang menggunakan sistem pengelolaan sampah swakelola yang diharapkan dapat mandiri dan produktif sehingga dapat memberikan manfaat bagi masyarakatnya di segala aspek. Penelitian ini menggunakan sumber data primer (observasi secara langsung) dan juga data sekunder, melalui wawancara, pengamatan, dokumentasi dan juga kepustakaan. Sedangkan metode analisis data yang digunakan adalah metode deskriptif.

Hasil yang didapat dari penelitian ini adalah benar bahwa keberhasilan program pengelolaan sampah swakelola di Kampung Sukunan merupakan hasil dari partisipasi masyarakatnya, dan pengelolaan sapah secara mandiri tersebut memberi manfaat yang positif bagi masyarakat baik dari segi sosial, ekonomi maupun kualitas fisik pembangunan Kampung Sukunan.
\end{abstract}

Kata kunci : pengelolaan sampah, partisipasi masyarakat.

\section{Pendahuluan}

Masyarakat dan lingkungan merupakan dua unsur yang tidak dapat dipisahkan dalam sebuah permukiman, dikarenakan kedua unsur tersebut saling mempengaruhi. Masyarakat melakukan aktivitasnya di dalam sebuah lingkungan baik lingkungan binaan maupun lingkungan alam, dan setiap aktivitas yang dilakukan oleh masyarakat tersebut akan menimbulkan dampak / perubahan bagi lingkungan. Keseimbangan antara alam, manusia dan lingkungan terbangun akan menghasilkan suatu harmonisasi yang juga akan meningkatkan kualitas lingkungan (Heinz Frick, 1988).

Namun melihat banyaknya peristiwa yang terjadi di Indonesia belakangan ini seperti menumpuknya sampah-sampah rumah tangga baik di TPA maupun di sungai dan tempat umum lainnya, pembuangan limbah pabrik secara sembarangan dan ilegal, serta berbagai peristiwa lain dengan dampak negatif terhadap lingkungan, hal tersebut menunjukkan menurunnya kualitas lingkungan kita sekarang ini. Keprihatinan pemerintah dan pihak-pihak swasta mengenai hal tersebut mulai disosialisasikan semenjak dideklarasikannya Peringatan Hari Lingkungan Hidup Sedunia tahun 2010 silam.

Salah satu upaya sosialisasi tersebut juga dilakukan oleh Pemerintah Yogyakarta dalam Peringatan Hari Peduli Sampah DIY yang dilaksanakan pada bulan Februari 2014 yang lalu. Aksi peduli sampah memang sedang gencar disosialisasikan baik oleh pemerintah maupun komunitas-komunitas peduli lingkungan hidup, karena permasalahan mengenai sampah merupakan permasalahan utama yang banyak terjadi di permukiman dan perkotaan. Adanya permasalahan sampah tersebut akan dapat ditangani dengan baik apabila terdapat partisipasi dari masyarakat dalam pengelolaannya. Dalam hal ini masyarakat akan bertindak sebagai subjek dan sampah sebagai objeknya. Partisipasi masyarakat sepenuhnya dianggap sebagai penentu keberhasilan suatu program pembangunan (Hariyono, 2007).

Penelitian ini mengangkat tema partisipasi masyarakat dalam pengelolaan sampah swakelola di 
Kampung Sukunan, Kelurahan Banyuraden, Sleman Yogyakarta, yang pada saat ini telah menjadi salah satu desa wisata dan juga desa percontohan yang banyak dikunjungi baik oleh masyarakat, instansi maupun sekolah. Dengan total 5 RT yang sebagian KK-nya berpendidikan dan berpendapatan menengah ke bawah, Kampung Sukunan dapat berkembang di segala aspek baik aspek lingkungan, sosial maupun ekonomi dengan adanya pengelolaan sampah swakelola tersebut.

Tujuan dari penelitian ini adalah untuk mengetahui sejauh mana keberhasilan program pengelolaan sampah di Kampung Sukunan yang menggunakan sistem pengelolaan sampah swakelola yang diharapkan dapat mandiri dan produktif sehingga dapat memberikan manfaat bagi masyarakatnya di segala aspek. Penelitian ini menggunakan sumber data primer (observasi secara langsung) dan juga data sekunder, melalui wawancara, pengamatan, dokumentasi dan juga kepustakaan. Sedangkan metode analisis data yang digunakan adalah metode deskriptif.

\section{Pengertian Sampah}

Menurut UU RI No.18 Tahun 2008 pasal 1 tentang pengelolaan sampah, sampah adalah sisa aktivitas sehari-hari manusia dan atau sisa dari proses alam yang berbentuk padat, sampah spesifik adalah sampah yang karena sifat, konsentrasi dan atau volumenya memerlukan pengelolaan khusus. Sedangkan pengertian sampah menurut SK SNI T-13-1990-F adalah limbah yang bersifat padat dan terdiri dari zat organik dan zat anorganik yang dianggap tidak berguna dan harus dikelola agar tidak membahayakan lingkungan dan melindungi investasi pembangunan.

Dalam Bahar (1986) menyebutkan mengenai identifikasi sampah menurut jenis-jenisnya :

- Sampah basah (garbage), adalah sampah yang berasal dari sisa pengolahan, sisa pemasakan ataupun sisa makanan yang telah membusuk tetapi masih dapat digunakan sebagai bahan makanan organisme lain.

- Sampah kering (rubbish), yaitu sampah sisa makanan yang tidak mudah busuk. Dapat dibagi menjadi 2 golongan : sampah kering yang mudah terbakar dan sampah kering yang tidak mudah terbakar.

Ashes dan cinder, adalah berbagai jenis abu dan arang yang berasal dari kegiatan pembakaran.

- Dead animal, yaitu sampah yang berasal dari bangkai binatang.

- Street sweeping, adalah sampah / kotoran yang berserakan di sepanjang jalan.

- Industrial waste, merupakan sampah yang berasal dari kegiatan industri. Sampah jenis ini biasanya lebih homogen dibanding dengan sampah lainnya.

\section{Pengelolaan Sampah}

Menurut UU RI No.18 Tahun 2008 tentang pengelolaan sampah, Pengelolaan sampah rumah tangga dan sampah sejenis sampah rumah tangga terdiri atas : pengurangan sampah dan penanganan sampah. Pengurangan sampah meliputi kegiatan :

- Pembatasan timbulan sampah

- Pendaur ulangan sampah

- Pemanfaatan kembali sampah

Sedang kegiatan penanganan sampah meliputi :

- Pemilahan, dalam bentuk pengelompokan dan pemisahan sampah sesuai dengan jenis, jumlah, dan atau sifat sampah.

- Pengumpulan, dalam bentuk pengambilan dan pemindahan sampah dari sumber sampah ke tempat penampungan sementara / tempat pengolahan sampah terpadu.

- Pengangkutan, yaitu membawa sampah dari sumber dan atau dari tempat penampungan sampah sementara atau dari tempat pengolahan sampah terpadu menuju ke tempat pemrosesan akhir.

- Pengolahan dalam bentuk mengubah karakteristik, komposisi dan jumlah sampah.

- Pemrosesan akhir sampah dalam bentuk pengembalian sampah dan atau residu hasil pengolahan yang sebelumnya menuju ke media lingkungan secara aman.

Untuk pengelolaan sampah spesifik menjadi tanggung jawab pemerintah.

Saat ini, pengelolaan sampah yang sering digunakan dalam masyarakat adalah $3 \mathrm{R}$ (reduce, reuse, recycle) yang berarti pengurangan, penggunaan kembali, dan pendaurulangan. Dalam Vesilind (2012) menjelaskan mengenai metode pengelolaan sampah sebagai berikut :

\section{Reduction (pengurangan)} tiga cara :

Pengurangan sampah dapat dicapai dengan

- Mengurangi jumlah bahan yang digunakan dari tiap produk tanpa mengorbankan fungsi produk

- Meningkatkan masa hidup suatu produk

- Mengurangi / menghilangkan kebutuhan penggunaan suatu produk

2. Reuse (penggunaan kembali)

Yaitu menggunakan kembali barang-barang yang sudah tidak digunakan dengan sebagaimana mestinya (penggunaan barang bekas)

3. Recycling (pendaurulangan)

Proses pendaurulangan membutuhkan pemisahan dari materi yang dapat digunakan dan tidak dapat digunakan. Materi sampah yang dapat didaurulang berupa sampah padat seperti kertas, logam, plastik, kaca, dan sampah dari lahan. 


\section{Recovery (pemulihan)}

Proses ini rata-rata digunakan untuk sampah yang terbuat tidak dari 1 material. Sebagai contoh : kaleng minuman, terbuat dari baja (steel), seng, dan kertas pembungkus pada bagian luar. Proses recovery ini melalui suatu mesin yang dapat memulihkan bagian tertentu dari produk sehingga dapat digunakan kembali.

5. Disposal of Solid Waste in Landfills (pembuangan sampah padat di lahan)

Sampah padat disini menjadi bagian dari bahan urugan tanah.

6. Energy Conversion (pengubahan energi)

Merupakan salah satu alternatif untuk memperoleh energi dengan penguraian dan pembentukan bahan bakar melalui pembakaran sampah sehingga didapat tekanan / panas.

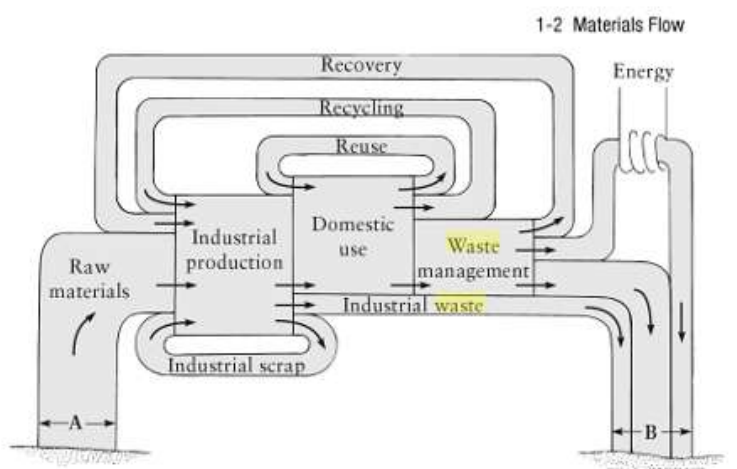

Gambar 1. Alur perputaran Sampah dalam Masyarakat

(Sumber : Vesilind, 2012)

\section{Partisipasi Masyarakat}

Masyarakat diharapkan dapat turut berperan serta dalam pengelolaan sampah di lingkungannya. Hal tersebut juga tertulis dalam UU RI No.18 Tahun 2008 tentang pengelolaan sampah. Peran masyarakat yang dimaksud terdapat pada pasal 28 ayat 1 , yaitu :

- Pemberian usul, pertimbangan dan saran kepada Pemerintah dan atau Pemerintah Daerah

- Perumusan Kebijakan pengelolaan sampah

- Pemberian saran \& pendapat dalam penyelesaian sengketa persampahan

Menurut Ife dalam Aryenti (2011), pemberdayaan masyarakat adalah suatu konsep peningkatan kualitas masyarakat sehingga masyarakat tersebut dapat menentukan masa depannya sendiri sesuai dengan sumber daya, kesempatan, keterampilan dan pengetahuan yang mereka miliki. Masyarakat adalah penghasil utama sampah, oleh sebab itu masyarakat harus bertanggung jawab terhadap sampah yang dihasilkan tersebut.
Ada beberapa tahapan yang harus dilalui dalam pemberdayaan masyarakat (Adi, 2002), yaitu:

- Tahap persiapan, berarti tahap mempersiapkan tenaga dan lapangan

- Tahap pengkajian, meliputi individu maupun kelompok masyarakat

- Tahap perencanaan, yaitu alternatif pembuatan program yang akan dilaksanakan

- Tahap pemformulasian rencana, aksi, cara dan langkah-langkah dalam mencapai tujuan program

- Tahap pelaksanaan program, yaitu implementasi program di lapangan

- Tahap evaluasi, penilaian dan pengawasan

- Tahap terminasi, yaitu mengakhiri suatu kegiatan

\section{Profil Kampung Sukunan}

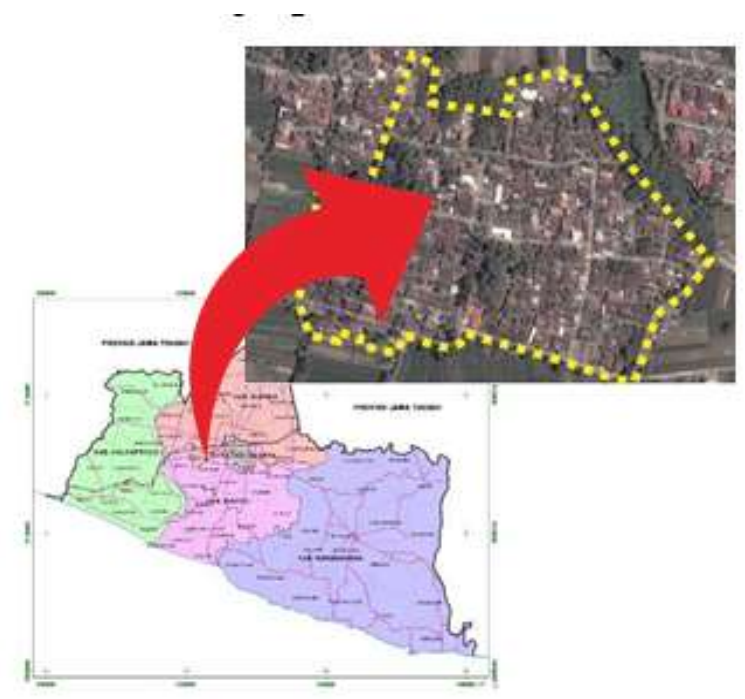

Gambar 2. Lokasi Kampung Sukunan

(Sumber : wikimapia.org / google.com, 2014)

Kampung Sukunan terletak di Kecamatan Gamping, Kabupaten Sleman, Provinsi Daerah Istimewa Yogyakarta. Kampung Sukunan mempunyai luas sekitar 42 Ha dan dihuni sekitar 800 jiwa dengan 250 Kepala Keluarga (KK) yang terbagi dalam 5 RT. Sebagian besar KK di Kampung Sukunan mempunyai mata pencaharian sebagai petani, buruh, pedagang dan usaha kecil rumahan, atau dapat dibilang bahwa sebagian besar warganya berpendidikan dan berpendapatan menengah ke bawah, hanya sebagian kecil yang menjadi karyawan swasta, PNS dan TNI.

Setelah melalui observasi di Kampung Sukunan, penyusun mendapati bahwa cukup banyak pendatang yang menghuni di wilayah tersebut, dan tampak sedikit kesenjangan dilihat dari bentuk huniannya dimana para pendatang memiliki rumah dengan pagar dan lebih tertutup, sedangkan warga asli Kampung Sukunan memiliki rumah sebagaimana mestinya bentuk rumah di 
desa yang sederhana dan tanpa pagar. Namun hal tersebut tidak menjadi suatu kendala yang berarti dalam pelaksanaan pengelolaan sampah swakelola, dikarenakan adanya hubungan yang saling membutuhkan satu sama lain.

Awal permasalahan pengelolaan sampah dirasakan oleh para petani yang sering menemukan buangan sampah di lahan mereka, selain itu banyak warga yang merasa bingung dan repot apabila harus membuang sampah mereka di TPS yang terletak cukup jauh dari Kampung Sukunan. Dengan adanya Pak Iswanto sebagai penggagas pengelolaan sampah swakelola mandiri dan produktif serta dibantu dengan pihak swasta sebagai donatur, warga Sukunan mulai mengembangkan sistem pengelolaan sampah tersebut yang dimulai dari tingkat rumah tangga hingga tingkat kelompok.

Pemilihan sistem pengelolaan sampah swakelola di Kampung Sukunan bertujuan untuk menangani permasalahan sampah secara mandiri oleh masyarakat, oleh karena itu pemulung tidak diijinkan masuk di lingkungan Kampung Sukunan. Dengan adanya sistem tersebut diharapkan akan tumbuh kesadaran masyarakat dalam menjaga lingkungan dan memperkuat rasa kepemilikan akan Kampung Sukunan sehingga warga akan lebih memberikan perhatian penuh terhadap kebersihan dan keindahan lingkungan tempat tinggal mereka.

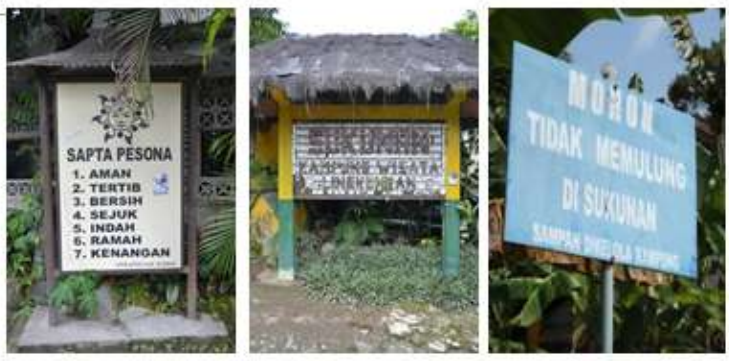

Gambar 3. Papan Tanda di Kampung Sukunan (Sumber : survey, 2014)

\section{Analisa Sistem Pengelolaan Sampah Kampung Sukunan}

Landasan penyusunan sistem pengelolaan sampah di Kampung Sukunan telah sesuai dengan penanganan sampah yang tertulis dalam UU RI No.18 Tahun 2008 mengenai Pengolahan Sampah, yaitu :

- Proses Pemilahan

Untuk menekan biaya operasional, pemilahan sampah dilakukan pada tingkat paling dasar / pada sumbernya, yaitu masing-masing rumah tangga. Pemilahan sampah tersebut dibagi ke dalam 5 kategori, yaitu :

1. Sampah organik, baik sampah daun / tanaman ataupun sampah sisa memasak akan dikumpulkan sendiri untuk kemudian diproses menjadi kompos (saat ini proses pengkomposan tersebut menggunakan komposter / gentong kompos).

2. Sampah kertas, kardus, koran, dll

3. Sampah kaca dan logam

4. Sampah plastik, kresek, gabus dan plastik kemasan

5. Untuk plastik kemasan (alumunium foil) akan dikumpulkan untuk dijadikan kerajinan tangan

6. Sampah B3 (Bahan Berbahaya dan Beracun)

7. Sampah B3 yang dimaksud seperti lampu, batre dan bahan-bahan lain yang bersifat mudah meledak, mudah terbakar, bersifat reaktif, beracun, dll.

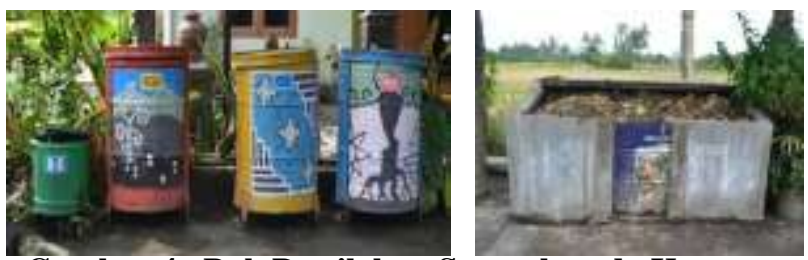

Gambar 4. Bak Pemilahan Sampah pada Kampung Sukunan (Sumber : survey, 2014)

\section{Proses Pengumpulan}

Dari masing-masing rumah tangga, kemudian sampah yang telah dipilah tersebut kemudian dikumpulkan oleh warga ke dalam bak sampah / tong sampah yang telah disediakan (dapat dilihat pada Gb.4 di atas)

\section{Proses Pengangkutan}

Setelah tong/ bak sampah penuh, sampah-sampah tersebut kemudian diangkut menuju

Tempat Penampungan Sampah (TPS) Kampung oleh Petugas. Biaya operasional petugas di sini akan diambil dari hasil penjualan sampah oleh pengepul sampah / lapak (rekanan). Sedangkan untuk sampah B3 akan menjadi tanggung jawab pemerintah maupun pemerintah daerah.

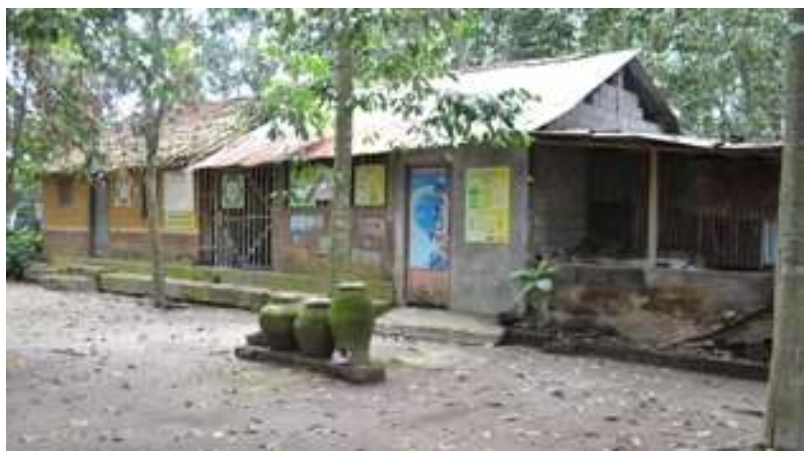

Gambar 5. Lumbung Sampah / TPS Kampung Sukunan. (Sumber : survey, 2014) 


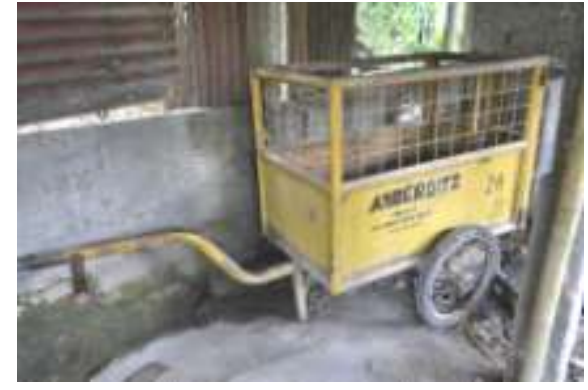

Gambar 6. Gerobag sampah sebagai alat angkut menuju TPS (Sumber : survey, 2014)

Gerobag sampah di atas merupakan hasil sumbangan dari Pemerintah Kab. Sleman. Namun pengadaan gerobag sampah tersebut ada setelah sistem pengelolaan sampah swakelola di Kampung Sukunan telah berjalan dengan baik, dengan kata lain respon dari Pemerintah baru ada setelah program tersebut terbukti dapat berjalan dan sukses.

\section{Proses Pengolahan}

Warga Kampung Sukunan hanya mengolah sampah organik (yang kemudian akan diolah menjadi kompos dan atau arang) dan sampah anorganik yang berupa kemasan (jenis sampah plastik tebal baik yang berlapis aluminium foil maupun tidak berlapis) untuk kemudian didaur ulang menjadi kerajinan tangan seperti tas, dompet, dll.
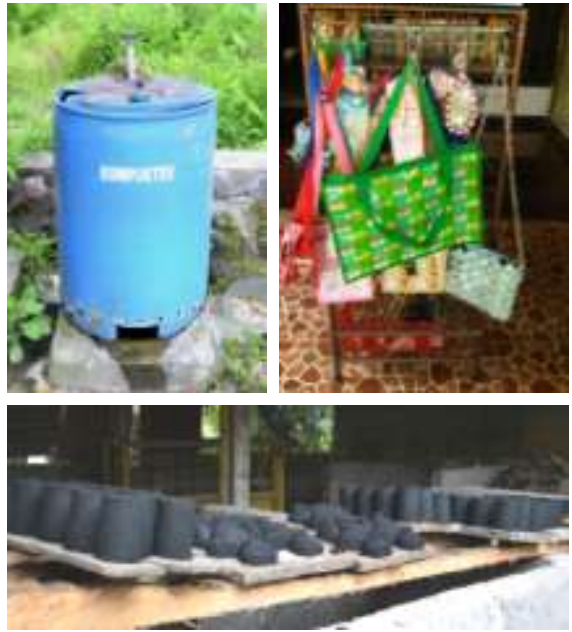

\section{Gambar 7. Komposter-kerajinan daur ulang kemasan-arang (Sumber : survey, 2014)}

\section{Pemrosesan Akhir Sampah}

Untuk hasil pengolahan sampah organik berupa kompos akan digunakan kembali oleh warga untuk penghijauan dan dapat dijamin kemanannya terhadap lingkungan. Untuk sampah / limbah cair dari rumah tangga akan melalui proses IPAL (instalasi pengolahan air limbah) sebelum kemudian kembali dialirkan menuju sungai / untuk mengairi lahan pertanian.

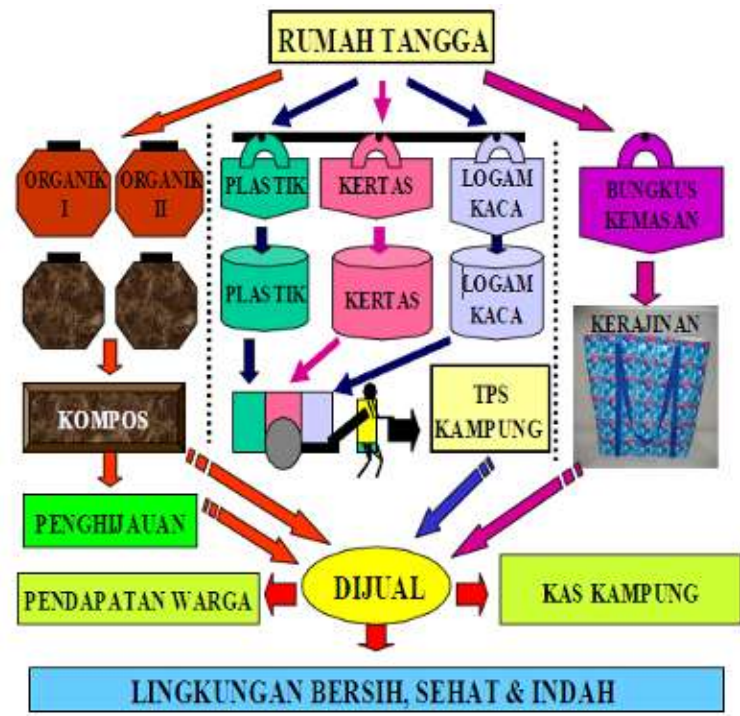

Gambar 8. Bagan Pengelolaan Sampah Kampung Sukunan (Sumber : data Kampung Sukunan, 2014)

Dari gambar 8 di atas, tampak bahwa pengelolaan sampah di Kampung Sukunan telah tersistem dengan baik, mulai dari pengelolaan sampah di tingkat masing-masing rumah tangga hingga tingkat Kampung yang membawahi 5 RT. Pengolahan sampah yang dilakukan tidak hanya mencakup 3R (reduce, reuse, recycle) atau pengurangan, penggunaan kembali dan pendaurulangan, namun juga recovery / pemulihan yang tampak dari pengolahan limbah cair dengan menggunakan IPAL, sehingga limbah cair rumah tangga yang kurang bersahabat dengan lingkungan dapat diolah terlebih dahulu untuk kemudian menjadi aman bagi lingkungan sebelum dialirkan kembali ke alam; penggunaan sampah padat yang tidak berbahaya seperti sisa bahan bangunan dll sebagai bahan urugan tanah; serta pengubahan energi / energy conversion berupa biogas yang mengubah sampah berupa kotoran ternak menjadi energi panas / api (dapat dilihat di Gambar 9).

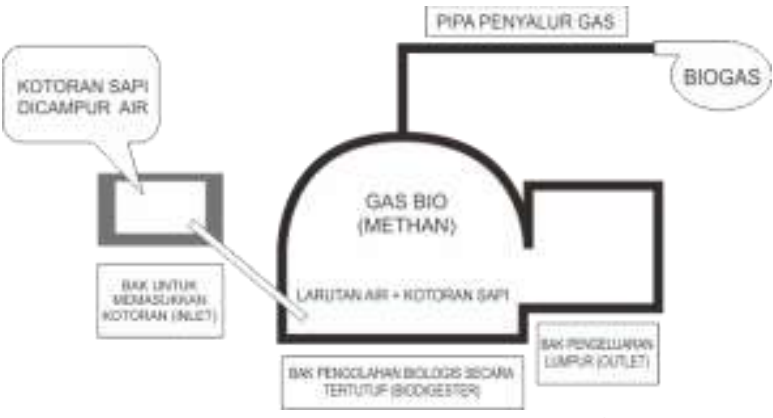

Gambar 9. Instalasi Biogas Kampung Sukunan

(Sumber : survey, 2014) 
Sistem Pengelolaan sampah tersebut tidak hanya dari segi mekanisme dan pelaksanaannya sajam, namun dari segi pembiayaan pun telah dipikirkan dengan baik oleh warga Kampung Sukunan, berawal dengan bantuan modal dari pihak swasta sebesar Rp 5.500.000,- yang digunakan oleh warga untuk membeli berbagai pelengkapan seperti kotak sampah dan komposter, hasil pemilahan dan pengolahan sampah tersebut kemudian dapat dijual dan hasilnya digunakan untuk biaya operasional petugas serta kas Kampung untuk pembangunan Kampung Sukunan. Dengan keberhasilan pengelolaan sampah swakelola yang mandiri dan produktif tersebut, tidak heran jika Kampung Sukunan saat ini telah menjadi salah satu Kampung Wisata dan juga menjadi desa percontohan yang sering pula dikunjungi oleh masyarakat, instansi maupun sekolah untuk dijadikan sebagai acuan dari sebuah Kampung dengan pengelolaan sampah terpadu berbasis masyarakat.

\section{Peran Serta Warga Kampung Sukunan}

Peran serta warga Sukunan tersebut tidak melalui proses yang instan, karena dalam pelaksanaannya juga melalui beberapa tahapan seperti proses sosialisasi sampai pada akhirnya program tersebut dapat terimplementasikan dengan baik. Tahapan-tahapan tersebut antara lain :

Penyampaian gagasan sistem pengelolaan sampah swakelola secara mandiri dan produktif pada tokoh masyarakat Sukunan.

Pembentukan Tim Pengelola Sampah Kampung Sukunan. Bersama dengan tokoh masyarakat, tim ini bertugas melakukan sosialiasi, edukasi, evaluasi dan motivasi secara konsisten pada masyarakat mengenai sistem pengelolaan sampah swakelola tersebut. Pemilihan Tim Pengelola merupakan suatu langkah penting, karena tidak mudah dalam mencari warga yang mempunyai dedikasi tinggi untuk pelaksanaan suatu program, apalagi program tersebut adalah program sosial yang manfaat \& hasilnya adalah untuk seluruh warga Kampung.

- Menyusun visi, misi dan slogan kampung untuk menyamakan persepsi dan memotivasi masyarakat.

Tahapan ini bermaksud untuk memperkuat kebersamaan antar warga dan meningkatkan kualita sosial masyarakat.

- Pelaksanaan sosialisasi, edukasi dan motivasi pada seluruh lapisan masyarakat dengan berbagai metode seperti demonstrasi, tanya jawab, permainan, seni mural dan permainan-permainan.

- Pengadaan Program Pelatihan, guna meningkatkan keterampilan masyarakat.

- Mempersiapkan sarana pendukung. Pengadaan dan pengerjaan semua sarana dilakukan oleh masyarakat, supaya masyarakat mempunyai rasa memiliki sehingga pada akhirnya akan menjaga dan menggunakan dengan baik.

- Mempersiapkan petugas dan atau menjalin kerjasama dengan pihak lain (dalam hal ini pengepul sampah). Namun sebelum ditawarkan kepada pihak lain, hendaknya ditawarkan terlebih dahulu kepada warga Kampung Sukunan sendiri. Dalam hal ini perlu adanya kesepakatan mekanisme dan tanggung jawab satu sama lain.

- Menghimbau masyarakat untuk segera menerapkan sistem pengelolaan sampah swakelola sesuai dengan mekanisme yang telah disepakati.

Hal ini tampak dari adanya peraturan dan himbauan yang terpampang di papan pengumuman dan di beberapa titik lokasi di Kampung Sukunan.

- Monitoring / pengawasan kegiatan pengelolaan sampah dan juga evalusi oleh tim pengelola sampah Kampung.

- Pelaporan hasil kegiatan pengelolaan sampah terhadap masyarakat.

Selain Pelaporan Hasil Penjualan Sampah yang terpampang di Lumbung Sampah, kegiatan pengelolaan sampah di Kampung Sukunan juga rutin dilaporkan dalam forum pertemuan warga setiap sebulan sekali.

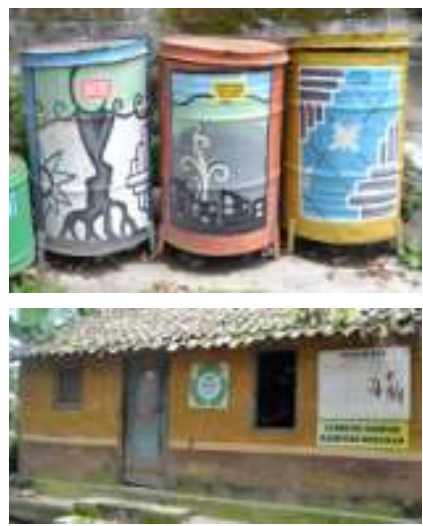

Gambar 10. Seni mural pada sarana\&prasarana pengelolaan sampah di Sukunan

(Sumber : survey, 2014)

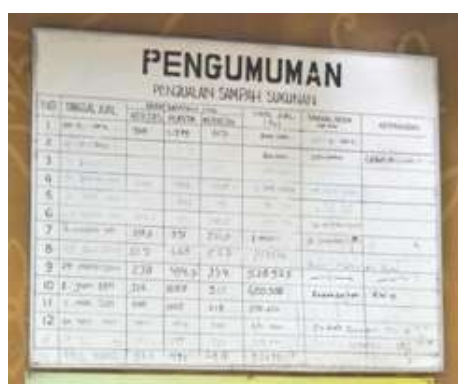

Gambar 11. Papan Pengumuman Hasil Penjualan Sampah Sukunan (Sumber : survey, 2014) 


\section{Hasil Dan Manfaat Sistem Pengelolaan Sampah Swakelola Di Kampung Sukunan Aspek Lingkungan}

Adanya peningkatan kualitas lingkungan dan juga kualitas hidup masyarakat di mana kesehatan warga lebih terjamin karena kebersihan lingkungan lebih terjaga dan terhindar dari pencemaran sampah, limbah, maupun zat-zat yang berbahaya bagi manusia. Hasil pertanian juga meningkat karena penggunaan kompos alami buatan masyarakat Sukunan sendiri yang berarti kandungan kompos tersebut juga lebih terjamin kealamiannya.

Dengan adanya partisipasi masyarakat serta kesadaran dan kebersamaan masyarakat yang kuat, pembangunan lingkungan Kampung juga semakin berkembang, hal tersebut tampak dari pembangunan fasilitas-fasilitas umum yang bermanfaat bagi seluruh warga Kampung Sukunan,seperti balai serba guna yang biasa digunakan para remaja dan ibu-ibu untuk membuat dan memamerkan barang kerajinan khas Kampung Sukunan, gapura jalan, , bak-bak kompos, seni mural yang menambah estetika lingkungan, dll.

Selain itu, dengan bertambahnya pengetahuan masyarakat akan lingkungan, saat ini sebagian masyarakat Sukunan telah jarang menggunakan komposter pada skala rumah tangga dan mulai beralih ke cara pengelolaan sampah dengan lubang biopori karena dianggap lebih praktis dan efisien. Hal tersebut memberi dampak yang positif karena dapat meningkatkan daya resap air pada tanah dan dapat menciptakan pori-pori dalam tanah.

\section{Aspek Sosial dan Ekonomi}

Dengan adanya sistem pengelolaan sampah swakelola oleh masyarakat Sukunan ini juga meningkatkan kualitas sosial masyarakat Sukunan, karena tingkat kebersamaan warga semakin tinggi. Selain itu karena warga merasa terlibat dalam pengelolaan dan pembangunan lingkungannya, secara tidak sadar rasa memiliki dan tanggung jawab warga terhadap lingkungan dan tempat tinggalnya akan semakin tinggi. Walaupun pada pelaksanaannya tidak sedikit pula warga yang skeptis dan menutup diri terhadap program pengelolaan sampah swakelola di Kampung Sukunan ini, namun hal tersebut tidak menjadi kendala yang berarti karena program ini tetap dapat terlaksana dengan baik.

Berbagai macam kunjungan dari instansi dan sekolah baik dalam maupun luar negeri pernah diterima oleh warga Sukunan, bahkan warga Sukunan juga sering diminta untuk memberikan penyuluhan di Kampung lain ataupun instansi. Hal tersebut menunjukkan bahwa peningkatan kualitas warga di Kampung Sukunan telah diakui dan warga Sukunan pun telah banyak berkembang dengan berbagai macam pengetahuan dan keterampilan yang telah mereka miliki dan mereka terapkan dalam kehidupan sehari-hari.
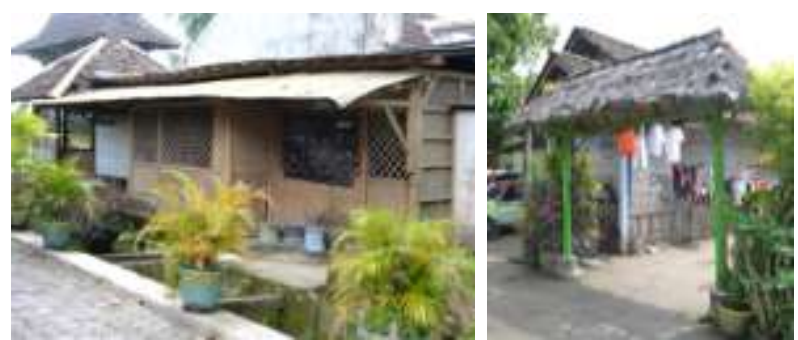

Gambar 12. Balai Serba Guna - Gapura Jalan (Sumber : survey, 2014)

Selain itu, dengan adanya pengelolaan sampah secara mandiri dan produktif tersebut, perekonomian warga Sukunan juga semakin meningkat. Hal itu tampak dari semakin berkembangnya usaha home industri dari warga Sukunan seperti pembuatan makanan khas Sukunan (peyek belut, jadah tempe, emping mlinjo, dll); berkurangnya jumlah pengangguran di Kampung Sukunan karena banyak pemuda yang semula adalah pengangguran, sekarang ini aktif dalam divisi perbengkelan Kampung Sukunan yang banyak menerima pesanan komposter dari luar; ibu-ibu yang semula hanya ibu rumah tangga saat ini dapat membantu perekonomian keluarga dengan membuat kerajinan daur ulang kemasan dan kain perca menjadi kerajinan tangan cantik seperti tas, dompet, dll yang kemudian dijual pada masyarakat \& pengunjung.

\section{Kesimpulan}

Dari hasil pengamatan dan observasi penyusun terhadap partisipasi warga Sukunan dalam pengelolaan sampah swakelola yang mandiri dan produktif, maka dapat ditarik kesimpulan sebagai berikut :

Suatu program yang bertujuan untuk pengembangan dan pembangunan lingkungan permukiman dapat berhasil dengan baik apabila masyarakat di dalamnya ikut berpartisipasi dan terlibat dalam semua tahapan pemberdayaan masyarakat.

Pengelolaan sampah secara mandiri di Kampung Sukunan membawa dampak dan manfaat yang positif tidak hanya bagi lingkungan namun juga bagi masyarakat baik dari segi sosial maupun ekonomi dan juga peningkatan pembangunan fisik Kampung Sukunan.

Program peduli lingkungan seperti yang dilakukan warga Sukunan tersebut hendaknya menjadi contoh dan acuan bagi lingkungan permukiman di daerah lain, karena hal tersebut sangat penting supaya dapat tercipta lingkungan permukiman yang berkelanjutan dan dapat dinikmati oleh generasi sekarang dan juga masa datang. 
ISSN : 0853-2877

\section{References}

Adi. Rukminto Isbandi, Pemikiran-Pemikiran Dalam Pembangunan Kesejahteraan Sosial, Lembaga Penerbit FE-UI, Jakarta, 2002

Anonim, Tata Cara Pengolahan Teknik Sampah Perkotaan, SK SNI-T-13-1990-F, Bandung : Yayasan LPMB, 1992

Aryenti, Peningkatan Partisipasi Masyarakat Dalam Pengelolaan Sampah Dengan Cara 3R Di Lingkungan Permukiman Ditinjau Dari Segi Sosial Ekonomi Masyarakat, Pusat Litbang Permukiman, Bandung, 2011

Bahar. Yul. H, Teknologi Penanganan dan Pemanfaatan Sampah, PT Waca Utama Pramaesti, Jakarta, 1986

Frick. Heinz, Arsitektur dan Lingkungan. Kanisius, Yogyakarta, 1988

Hariyono. Paulus, Sosiologi Kota Untuk Arsitek, PT Bumi Aksara, Jakarta, 2007

Perda DIY Nomor 07 Tahun 2012, tentang Rencana Pembangunan Jangka Menengah Kota Yogyakarta tahun 2012 - 2016

Tim Penulis PS, Penanganan dan Pengolahan Sampah, Penebar Swadaya, Depok, 2008

UU RI No.18 Tahun 2008 tentang Pengelolaan Sampah

Vesilind P.A ; Worrell W.A, Solid Waste Engineering (Second Edition), Global Engineering, Stamfors CT 06902 : USA, 2012. 